\title{
SPATIAL AND TEMPORAL VARIATIONS OF PHYSICO-CHEMICAL VARIABLES IN A SMALL 'PRISTINE' STREAM IN NIGER DELTA, NIGERIA
}

\author{
SIKOKI, F. D. and I. N. ANYANWU \\ Department Of Animal and Environmental Biology, University Of Port Harcourt
}

Copyright 2010, Fisheries Society of Nigeria.

This paper was prepared for presentation at the $25^{\text {th }}$ Annual International Conference and Exhibition in Administrative Staff College of Nigeria (ASCON), Topo-Badagry, Lagos, Nigeria, $25^{\text {th }}-29^{\text {th }}$ October, 2010.

This paper was selected for presentation by an FISON Program Committee following review of information contained in an abstract submitted by the author(s). Contents of the paper, as presented, have not been reviewed by the Fisheries Society of Nigeria and are subject to correction by the author(s). The material, as presented, does not necessarily reflect any position of the Fisheries Society of Nigeria, its officers, or members. Papers presented at FISON meetings are subject to publication review by Editorial Committees of the Fisheries Society of Nigeria. Electronic reproduction distribution, or the Fisheries Society of Nigeria. Electronic reproduction, distribution, or storage of any part of this paper for commercial purposes without the written consent of the Fisheries Society of Nigeria is prohibited. Permission to reproduce in print is restricted to an abstract of not more than 300 words; illastrations may not be copied. The abstract must conspicuous acknowledgement of where and by whom the paper was presented. Write Librarian, Fisheries Society of Nigeria (FISON), P. O. Box 2607 Apapa, Lagos.

\section{ABSTRACT}

Spatial and temporal variations of physico-chemical variables of Onu-Iyi Ukwu stream were studied for 12 months from March 2005 to February 2006. Three sampling stations were established along the main stream channel from source to mouth. Spatial variation in physicochemical parameters indicated that total alkalinity, total hardness, conductivity, and nitrate-nitrogen $\left(\mathrm{NO}_{3}\right)$ recorded their highest values at the upper reaches (with values $14.0 \mathrm{mg} / \mathrm{l}, 88.09 \mathrm{mg} /, 17.00 \mu \mathrm{scm}$, and $0.60 \mathrm{mg} / \mathrm{l}$ respectively). Dissolved Oxygen (DO) and $\mathrm{pH}$ had their maximum values of $8.20 \mathrm{mg} / \mathrm{l}$ and 6.94 at the middle reaches. Turbidity, biochemical oxygen demand (BOD), temperature and phosphate-phosphorus $\left(\mathrm{PO}_{4}\right)$ increased steadily from source to mouth. The observed seasonal variation indicated that wet season values were higher for all the parameters except temperature, turbidity, phosphate-phosphorus $\left(\mathrm{PO}_{4}\right)$ and total alkalinity although the values were not statistically significant at $p>0.05$. The correlation coefficient ( $r$ ) showed no significant relationships $p<0.05$ between physico-chemical parameters except $D O$ and BOD with correlation values of $(0.75$ and -0.54) respectively.

\section{INTRODUTION}

Studies on physico-chemical parameters of the rivers, tributaries and streams in eastern Nigeria are few and the available ones are mostly of short term duration and are based on a few specific samples, which are not significant in terms of baseline data necessary for future studies and for monitoring. They include Ekeh; I.B (1988) unpublished, Nwadiaro (1987), Odigi and Nwadiaro (1988), Nwadiaro and Umeham (1985), Nwadiaro (1982).

Both aquatic and terrestrial life requires water for support, movement, feeding and for maintenance of body functions. The physical and chemical properties of water can therefore directly or indirectly affect aquatic life. The movement of water from a high altitude to a lower one is due to its physical properties such as surface tension and viscosity. Movement of water may erode the land over which it flows, carrying along with it large amounts of suspended solids which will affect its ability to support plant and animal life by increasing its turbidity, reducing light penetration and in areas of where the current velocity is slow, the suspended materials settle on the bottom and affect benthic organism. Water is also a good solvent for various chemical compounds required by all aquatic organisms to survive. Two gases, carbon and oxygen exist in water and each dissolves at a different rate and the amount dissolved is affected by temperature.

There is no information concerning the physico- chemical hydrology of Onu-IyiUkwu stream. This study provides preliminary data which can be used for future monitoring and assessment of pollution and degradation of the Onu-IyiUkwu stream. 


\section{MATERIALS AND METHODS}

\section{Study Area}

Onu-Iyi-Ukwu stream is located in Akabor, Ahiara-Mbaise, Imo State Nigeria on approx. latitude $5^{\circ} 30^{\prime} \mathrm{N}$ and longitude $7^{\circ} 19^{\prime} \mathrm{E}$. The stream originates as a spring from a neighbouring Local Government Isiala Mbano in Imo State and joins two other streams Iyi-Uzo-Aku and Uramiriukwa before emptying into the Otamiri River, a major tributary of the Imo River.

\section{Field Procedures}

The three sampling stations were sited at lower; middle and upper reaches. Station 1 was located upstream and station 3 downstream.

Water samples for physico-chemical analysis were collected using plastic containers. Samples were collected once a month from March 2005 to February 2006 at the surface and confined to the mid stream water. Samples were analyzed within 48 hours after collection with no preservatives used. Samples for dissolved oxygen and biochemical oxygen demand were collected with $250 \mathrm{ml}$ Nestlé's bottles and fixed in situ. Water temperature measurements were done at site, using mercury in glass thermometer.

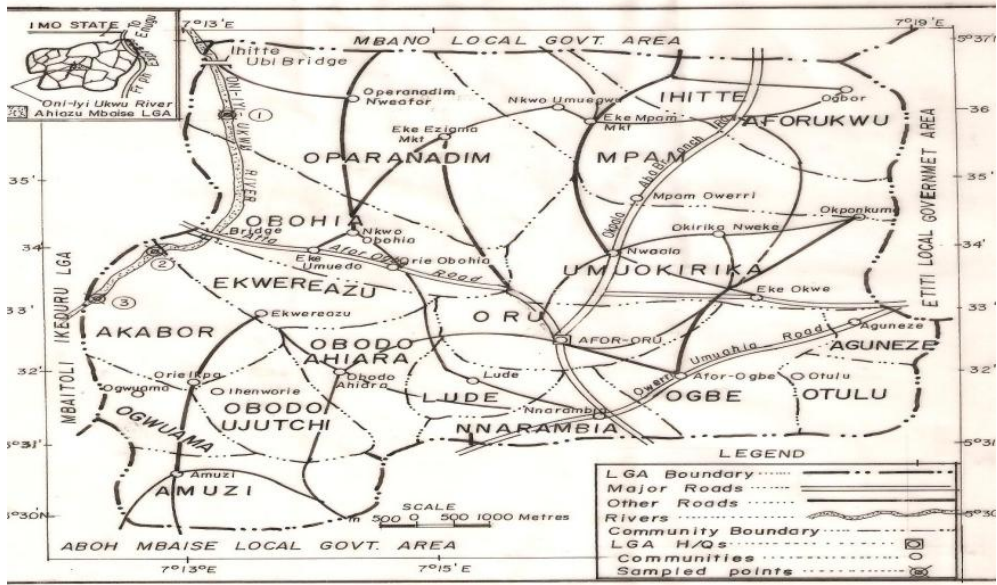

Fig 1: Ahiazu Mbaise Local Govt Area showing Onu-Iyi-Ukwu River and sampled points

\section{Laboratory Procedure}

The physico-chemical analysis of water samples followed the standard limnology methods of APHA (1975). $\mathrm{pH}$ was measured with a $\mathrm{pH}$ meter (model 3015 jenway), using $\mathrm{pH}$ buffer solution of 4.0, 7.0, and 9.0. Turbidity was determined using spectro-photometric method at 420 $\mathrm{nm}$. Total alkalinity was determined using titrimetric method (APHA, 1975) with a $0.2 \mathrm{n} \quad \mathrm{H}_{2} \mathrm{SO}_{4}$ and methylated orange indicator. Nitrate-Nitrogen was measured using the brucine method (APHA, 1975) while conductivity was determined using a conductivity meter (Jenway model 4010). Phosphate-Phosphorus was determined by the ascorbic acid method (APHA, 1975), total hardness by titrimetric method using ethylene diaminetetracetic acid (EDTA) (APHA, 1975). Dissolved oxygen (DO) and biochemical oxygen demand (BOD) were determined using the modified Azide method (APHA, 1975).

\section{Results}

Surface water temperature during each month showed seasonal variation. All reaches noted peak values in February. Lower values were recorded between August and October. All stations showed definite pattern of increased values from August to February. The seasonal variation 
was found with higher readings in the dry season at all the stations (Table 2). These seasonal differences were statistically nonsignificant at the upper reaches and negatively significance at the middle and lower reaches. Correlation showed nonsignificant values.

BOD values ranged from $3.8 \mathrm{mg} / \mathrm{l}-22.4$ $\mathrm{mg} / \mathrm{l}$ (Table 1). The highest monthly variation occurred in the lower reaches. Higher values were observed in the wet than dry season (Table 2) with nonsignificant differences at all the reaches. There was a significant positive correlation at the upper reaches and negative correlation at the middle and lower reaches $(\mathrm{r}=0.61,-0.55,-0.54)$.

DO values ranged from $2.00-8.20 \mathrm{mg} / \mathrm{l}$ (Table 1). All the stations showed peak values of $8.0 \mathrm{mg} / \mathrm{l}$ in February 2006. The wet season values were slightly higher than dry season value with no significant difference between seasons. There was a positive correlation between the seasons at stations 1 and 3 (Table 2).

$\mathrm{pH}$ values peaked in June, July and February at all stations. Variability was highest at the lower reaches and lowest at the upper reaches. The upper and middle reaches recorded higher wet season values than dry season values but no significant difference was found between the seasons. There was a negative correlation at station 1 and 3 (Table 2).

The monthly variation of turbidity was dramatic at the various stations. Periods of low and high values in August and September coincided with all reaches. Values were highest at all stations in November and lowest in March. The pattern of variation recorded dry season maximum against wet season minimum in all the stations with a non-statistical level of significance (Table 2). Correlation coefficient for the two seasons indicated a negative non-significant correlation (Table 2).

Total hardness_varied monthly at all the stations. High monthly variation occurred at the upper reaches while low variation occurred in the lower reaches. Total hardness showed dry season maximum and wet season minimum. However, the lower reaches recorded an increase in wet season value against dry season. These difference were statistically non significant. A non significant negative correlation was also recorded in all the stations (Table 2).

Total alkalinity peaked in January with values ranged from 0.50-14.40 (Table 1). Alkalinity data showed dry season maximum and wet season minimum values (Table 2), with a non-significant difference between the seasonal values at all the stations. However, the Upper reaches showed a negative correlation, while the middle and lower reaches indicated a positive non-significant correlation.

Nitrate varied independent of season as high and low values occurred at both dry and wet season months. The pattern of fluctuation produced several peak and low values at each station. All stations recorded peak values in the month of July. Wet season values were higher than dry season values by $0.1 \mathrm{mg} / \mathrm{l}$ but differences were not statistically significant. The correlation coefficient for the seasons showed negative correlation at all the reaches (Table 2).

Phosphate showed a definite pattern as no values were recorded from May 2005 to January 2006. February observed the lowest $0.009 \mathrm{mg} / \mathrm{l}$ in all the stations and the highest values occurred in April with values of 1.6 and $1.8 \mathrm{mg} / \mathrm{l}$ in middle and lower reaches. A non significant difference exists at the reaches. Correlation coefficient for the two seasons showed zero correlation.

The monthly variations in electrical conductivity at various stations ranged from 6.00-17.00 $\mu \mathrm{scm}-1$ at the upper reaches. The lowest conductivity value $6.0 \mu \mathrm{scm}^{-}{ }^{1}$ occurred in March and the highest $17.0 \mathrm{\mu scm}^{-}{ }^{1}$ in August). Conductivity showed no seasonal variation at all the reaches as wet season maximum value of $8.67 \mu \mathrm{scm}^{-}{ }^{1}$ and minimum dry of 
$8.0 \mu \mathrm{scm}^{-1}$ were obtain at the lower reaches with a non-significant difference between the seasonal values. Correlation ( $r$ ) showed that upper reaches had a non significant negative relationship while middle reaches, recorded a significant negative correlation and lower reaches recorded no correlation at all (Table 2).

\section{DISCUSSION}

The water temperature range of 25.5 $29.2^{\circ} \mathrm{C}$, falls within the range noted in some tropical rivers. Alabaster and Lloyd (1980), recorded $25^{\circ} \mathrm{C}-35^{\circ} \mathrm{C}$, Egborge and Jolomi (1986) observed $25^{\circ} \mathrm{C}-31^{\circ} \mathrm{C}$, Ekeh and Sikoki (2003), recorded $23.2^{\circ} \mathrm{C}$ $31^{\circ} \mathrm{C}$ in New Calabar River. The increased temperature values towards lower reaches have also been reported in other tropical rivers. The dense tree canopy at the upper reaches which shades the water from solar radiation is partly responsible for the observed temperatures at the upper reaches.

The range of turbidity values $(0.00-4.00$ $\mathrm{nm}$ ) reported in the study agrees with the observed ranges in New Calabar River were Ekeh (1998) recorded a range of 0.4 3.32 as well as the observed values with ranges of $30.0-101.5 \mathrm{~cm}$ recorded at Mfang-Mfang stream. The minimum turbidity at the upper reaches agrees with the finding of Ekeh (1998) at New Calabar River. Maximum turbidity at lower reaches is attributed to high input of allochthonous material during the period of high water and also due to human activities.

The observed range of BOD (3.84 - 22.40 $\mathrm{mg} / \mathrm{l})$ in the study is higher than some tropical rivers studied. Ekeh and Sikoki (2003) recorded $0.2-6.8 \mathrm{mg} / \mathrm{l}$ values in the New Calabar River. Odokuma and Okpokwasili (1996) recorded 0.25 - 4.20 $\mathrm{mg} / \mathrm{l}$ at the middle of New Calabar River. The higher range of $22.4 \mathrm{mg} / \mathrm{l}$ observed could be attributed to increase decay of organic matter from anthropogenic sources particularly at the lower reaches. This agrees with level of $6.25 \mathrm{mg} / \mathrm{l}$ BOD at Njaba River near its deltaic end (Nwadiaro et al, 1982). The observed value of BOD at the lower reaches of the study depicts the River as clean in the upper reaches but polluted in the lower reaches. However, the highest BOD recorded in the study exceeds the limits of international standard for water quality. The difference observed between the stations could be attributed to high organic load from human perturbations and influx of allochthonous materials from surrounding environment through erosion.

The observed range of Dissolved Oxygen $2.0-8.2 \mathrm{mg} / \mathrm{l}$ indicated low oxygen level which agrees with findings of low oxygen level in New Calabar River (Ekeh and Sikoki, 2003). The range is similar to values obtained from other studies such as New Calabar River 4.5 - 9.9 mg/l (King and Nkata, 1991) $3.5-7.5 \mathrm{mg} / \mathrm{l}$ in Bonny River (Chinda and Pudo, 1991), $6-8 \mathrm{mg} / \mathrm{l}$ in Densu River (Biney, 1991) and 7.29 $\mathrm{mg} / \mathrm{l}$ in some rivers in the Niger Delta (Nwadiaro et al, 1982). The low Dissolved Oxygen observed is probably due to organic detritus and human interferences particularly at the lower reaches. The variation of DO along the stream indicated that, the lower values at the lower reaches could be due to shading by surface by surface floating aquatic macrophytes such as Tania sp, Pistia sp and Azolla sp. Pennak (1971), reported that shading by macrophytes reduce photosynthesis in water as well as dissolved oxygen value. The low DO obtained at the lower reaches of Onu-Iyi-Ukwu stream is chiefly caused by high BOD probably due to organic matter from human activities (such as washing off melon, bread fruit etc) and also due to influx of allochthonous materials during the periods of high water. The $\mathrm{pH}$ concentration (Hydrogen ion concentration) range from 4.47 - 6.94 depicts acidic water conditions. The observed $\mathrm{pH}$ range is similar to the range recorded in other studies of Nigerian rivers. Ogan (1982) recorded $\mathrm{pH}$ of 5.6 6.0 in some rivers in Port Harcourt. Nwadiaro et al (1982) recorded 5.7, in Imo 
River, 6.1 Obigbo, and 5.7 Aluu. The result of hydrogen ion concentration in this study depicted the stream is a clear acidic water type. Similar observations of acidic fresh water have been reported by Moses (1979) in Cross River systems and Ekeh (1988) in Nworie stream.

The range of total alkalinity observed can be referred to as soft water with low total alkalinity values of $0.50-14.4 \mathrm{mg} / \mathrm{l}$. The values in this study could be regarded as low, with consequent low biological production. Nwadiaro et al (1982) reported similar low value of $10-17.5 \mathrm{mg} / \mathrm{l}$ in Imo River at Obigbo. Ekeh, 1998 (unpublished data) recorded low values of total alkalinity of $1-15 \mathrm{mg} / \mathrm{l}$ at the upper reaches of New Calabar River. The high values of total alkalinity at the upper reaches agrees with results obtained in Cross River Systems (Moses, 1979) who reported that total alkalinity was higher in the upper reaches than lower reaches.

Total hardness in this study, $4.0-80.09$ falls within the range recorded by other workers. Total hardness in surface waters is largely attributed to the calcium and magnesium carbonates. Ekeh and Sikoki (2003) recorded $1.0-1872 \mathrm{mg} / \mathrm{l}$ in New Calabar River. Hall et al (1977) observed range of $40-50 \mathrm{mg} / \mathrm{l} \mathrm{CaCO}_{3}$ in River Zambesi which agrees with the high value in the present study. Ogan (1988) noted low range of $0.01-0.25 \mathrm{mg} / \mathrm{l}$ in rivers in Port Harcourt in contrast. The high values of total hardness at the upper reaches and low value at the lower reaches agreed with observations of Moses (1979) in Cross River systems.

The electrical conductivity range of 6.0 $17.0 \mu \mathrm{scm}$ is lower than values recorded in the New Calabar River (Ekeh and Sikoki, 2003). However, the observed range agrees with results of some tropical Rivers. Sikoki and Veen (2004), recorded values 3.8 - $10.0 \mu \mathrm{mhos} / \mathrm{cm}$ in Shiroro Lake. Grerrarth and Deny, (1979) $8.1 \mu \mathrm{scm}$ for coastal lakes at Sierra Leone, while Moses, (1979) reported 6-25 $\mu \mathrm{scm}$ in Cross River Systems. The Longitudinal variation in conductivity showed higher values in the upper reaches than lower reaches. This result did not conform to observations of Moses, (1979) in Cross River Systems and Ekeh and Sikoki (2003) in New Calabar River who reported low conductivity value at the upper reaches and high values at the lower reaches.

The $0.00-0.6 \mathrm{mg} / \mathrm{l}$ range of NitrateNitrogen concentration observed conforms to values of other African Rivers. Sikoki and Veen 2004, recorded values ranging from $0.9-86 \mathrm{mg} / \mathrm{l}$ in Shiroro Lake; Soko River, 0.1 - $0.44 \mathrm{mg} / \mathrm{l}$ (Holden and Green, 1960), River Zambesi, 0.1 - $0.30 \mathrm{mg} / \mathrm{l}$ (Hall et al, 1977), $0.00-0.10 \mathrm{mg} / \mathrm{l}$ in some rivers in Port Harcourt (Ogan, 1988), $0.0-0.3 \mathrm{mg} / \mathrm{l}$ in at Warri River (Egborge and Jolomi, 1986) and $0.0-0.21$ at New Calabar River (Ekeh and Sikoki, 2003). Nitrate concentration in the stream showed variation with maximum values occurring at the upper reaches and minimum at the lower reaches. This agrees with observations of Akpan and Offem (1993) in Cross River, with reduced values towards lower reaches. This contrasts with Ekeh and Sikoki (2003) in New Calabar River. This could be due to decayed organic matter.

Phosphate is one of the principal nutrients that limit productivity of tropical waters (Raymont, 1980; cited in Ekeh, 1998). The occurrence of phosphate-phosphorus in low concentrations in Onu-Iyi-Ukwu stream is in line with the concentrations in other unpolluted tropical waters. Ogan (1988) recorded values of $1.0 \mathrm{mg} / \mathrm{l}$ in Port Harcourt River. Adeniyi (1979) noted 1.9 $\mathrm{mg} / \mathrm{l}$ in Lake Kainji, Nwadiaro and Umeham (1985) recorded trace to less than $1.0 \mathrm{mg} / \mathrm{l}$ in Oguta Lake while Hall et al (1977) recorded $0.11-0.37 \mathrm{mg} / \mathrm{l}$ in River Zambesi. Also Sikoki and Veen (2004) recorded low values in Shiroro Lake.

The high phosphate values observed at the middle and lower reaches with very low value at the upper reaches agrees with the findings of Ekeh (1998) in New Calabar 
River and Akpan and Offem, (1993) in Cross River.

\section{REFERENCES}

Akpan,E and Offem J.O. (1993). Seasonal variation in water quality of the Cross River, Nigeria. Hydrobiol, 35.275-284.

Anyanwu, I.N. (2006). Preliminary Studies of the Ichthyofauna and PhysicoChemical Properties of Onu-IyiUkwu Stream in Imo State Nigeria (unpublished data).

Biney, C.A. (1990). A review of some characteristics of freshwater and coastal ecosystem in Ghana. Hydrobiologica 208:45-53.

Egborge, A.B.M. and Jolomi B. (1986). Water quality index:

Environmental pollution series 8 $12(27-40)$.

Ekeh, I.B. and Sikoki, F.D. (2003). The State and Seasonality Variability in some physic chemical parameters of the New Calabar River, Nigeria. Hydrobiol.5

Gerrath, J.F and Denny, P (1979) Freshwater algae of Sierra Leone. Euglenophyta nova. Hedwigis, 31. $525-565$.

Hall, A.,Valente, I.M. and Davis, B.R. (1977). The Zambesi River in Mozambique: The hysico-chemical status of the middle and lower Zambesi prior to closure of the Cobora Bassa Dan. Freshwater Biol.7. 187-206.

Holden, M.J and Green, J (1960) The hydrology and plankton of the River Sokoto. J.Anim. Ecol. 29. 6584.

King, R.P and Nkata, N.A (1991) The status and seasonality of the physic-chemical Hydrology of a
Nigerian rainforest pond J. Limno. 52 (1) 1-12.

Moses, R.S (1979) The Cross River, Nigeria. Its ecological and fisheries in: proceedings of the International Conference on the Kainji Lake and River Basin Development in Africa. Kainji Lake Res. Inst. New Bussa.

Nwadiaro, C.S (1987) Depth variati on in the chemistry of Oguta Lake in south-eastern Nigeria Hydrobiol. Bull. 21:133-140.

Nwadiaro, C.S. and Umeham, S.N. (1985). The chemical hydrology of Oguta Lake, Southern Nigeria Hydrobiol. 108(2):251 - 269.

Nwadiaro, C.S., Oranusi, N.A. Umeham, S.N. (1982). Preliminary survey of the drinking water Quality of some areas in Imo and Rivers States. Proceedings of the $3^{\text {rd }}$ National conference of water pollution. Nigerian Agip Oil Company Conference Hall. Port Harcourt.

Odokuma, L.O. and Okpokwasili G.C (1996) Seasonal influence on the organic pollution Monitoring of the New Calabar River, Nigeria. Environmental monitoring Assessment, 12. 20-25 pp1-4.

Ogan. M.T. (1988) Examination of surface waters used as sources of supply in the Port Harcourt area 11. Chemical hydrology, Arch. Hydrobiol. Suppl. 79.(23): 325 342.

Pennak, R.W. (1971). Towards a Classification of Lotic habitats. Hyrology Vol. 38(2): 321 - 334.

Sikoki, F.D and Veen, J.V (2004) Aspects of water quality and potential for fish production of Shiroro Reservoir, Nigeria. Liv. Sys. Sus. Dev., 2. 7pp 
Table 1: Mean and Standard Deviations of Physico-Chemical Parameters for Stations 1-3 of the Onu-IyiUkwu Stream March-February 2006 UPPER REACHES

\begin{tabular}{|c|c|c|c|c|c|c|c|c|c|}
\hline & & & & & & & & & \\
\hline PARAMETERS & Mean \pm SD & Min & Max & Mean \pm SD & Min & Max & Mean \pm SD & Min & Max \\
\hline$\overline{\mathrm{BOD}}(\mathrm{mg} / \mathrm{l})$ & $10.28 \pm 2.17$ & 6.40 & 14.40 & $9.85 \pm 3.90$ & 6.40 & 20.00 & $9.51 \pm 5.49$ & 3.84 & 22.40 \\
\hline $\mathrm{DO}(\mathrm{mg} / \mathrm{l})$ & $5.90 \pm 1.61$ & 2.00 & 8.00 & $5.72 \pm 1.86$ & 2.40 & 8.20 & $5.80 \pm 1.63$ & 2.00 & 8.00 \\
\hline $\mathrm{pH}$ & $6.19 \pm 0.55$ & 5.30 & 6.76 & $6.15 \pm 0.75$ & 4.47 & 6.94 & $6.06 \pm 0.65$ & 4.90 & 6.93 \\
\hline TURBIDITY (nm) & $0.44 \pm 0.87$ & 0.00 & 3.00 & $0.59 \pm 0.84$ & 0.00 & 3.00 & $0.70 \pm 1.10$ & 0.00 & 4.00 \\
\hline TOTAL ALK.(mg/l) & $3.67 \pm 3.62$ & 1.20 & 14.40 & $2.78 \pm 1.84$ & 0.75 & 7.20 & $2.85 \pm 1.71$ & 0.50 & 7.20 \\
\hline TOTAL HARDNESS $(\mathrm{mg} / \mathrm{l})$ & $22.81 \pm 28.95$ & 5.60 & 88.09 & $26.13 \pm 23.41$ & 4.40 & 80.08 & $24.44 \pm 22.60$ & 4.00 & 80.08 \\
\hline NITRATE (mg/l) & $0.24 \pm 0.17$ & 0.00 & 0.60 & $0.13 \pm 0.10$ & 0.00 & 0.33 & $0.16 \pm 0.13$ & 0.00 & 0.47 \\
\hline PHOSPHATE $(\mathrm{mg} / \mathrm{l})$ & 0.00 & 0.00 & 0.01 & $0.13 \pm 0.46$ & 0.00 & 1.60 & $0.15 \pm 0.52$ & 0.00 & 1.80 \\
\hline CONDUCTIVITY $(\mu \mathrm{scm})$ & $9.75 \pm 3.41$ & 7.00 & 17.00 & $8.42 \pm 1.08$ & 7.00 & 10.00 & $8.33 \pm 1.67$ & 6.00 & \\
\hline TEMPERATURE $\left(0^{\circ} \mathrm{C}\right)$ & $27.27 \pm 1.06$ & 25.50 & 29.10 & $27.61 \pm 1.04$ & 25.50 & 29.20 & $27.61 \pm 1.05$ & 25.50 & \\
\hline
\end{tabular}

Table 2: Mean Wet and Dry Season values of the Physico-Chemical Parameters, Standard Deviation (in bracket), t-test and Correlation Co-efficient (r)

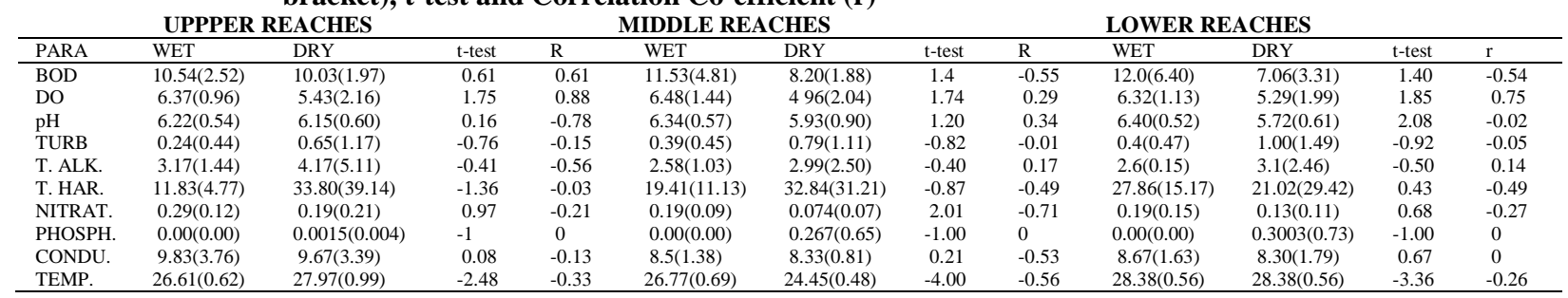

